\title{
Late Saalian and Eemian Interglacial at the Struga site (Garwolin Plain, central Poland)
}

\author{
ALEKSANDRA BOBER ${ }^{1, *}$, IRENA AGNIESZKA PIDEK ${ }^{1}$ and MARCIN ŻARSKI ${ }^{2}$ \\ ${ }^{1}$ Faculty of Earth Sciences and Spatial Management, Maria Curie-Skłodowska University in Lublin, \\ al. Kraśnicka 2d, 20-718 Lublin, Poland; e-mail: aleksandra.bober@umcs.pl, i.pidek@poczta.umcs.lublin.pl \\ ${ }^{2}$ The Polish Geological Institute - National Research Institute, Rakowiecka 4, 00-975 Warszawa, Poland; \\ e-mail: mzar@pgi.gov.pl
}

Received 8 March 2018; accepted for publication 19 June 2018

\begin{abstract}
The paper reports pollen analyses of 47 samples from palaeolake sediments at WH-15 Struga near Puznówka on the Garwolin Plain in central Poland. The pollen succession covers Late Saalian (MIS-6) and fully developed Eemian (MIS-5e) successions. The Late Saalian section is well developed (more than $2 \mathrm{~m}$ thick) and contains sub-zones reflecting the alternating dominance of steppe-tundra and boreal forest communities. The analysed Eemian succession is an uncommon succession described as a variant with early appearance and culmination of Tilia. In these terms, the successions of WH-15 Struga resemble those of sites of the Eemian interglacial known from the vicinity of Warsaw: Błonie, Warszawa-Żoliborz and Warszawa-Wola. The WH-15 Struga site is one of several recently discovered fossil sites of Eemian lakes on the Garwolin Plain, constituting the southern fragment of the extensive Eemian lakeland in the Polish Lowland.
\end{abstract}

KEYWORDS: Pleistocene, Eemian interglacial, MIS-5e, Late Saalian glacial, MIS-6, Garwolin Plain, central Poland

\section{INTRODUCTION}

The vast majority of sites with limnic sediments of the Eemian interglacial in Poland occur along a latitudinal belt in the central and eastern parts of the country, between the maximum range of the last phase of the Weichselian glaciation (MIS-2) and the maximum range of the Saalian glaciation (MIS-6) (Bruj \& Roman 2007). Sites with limnic sediments occur sporadically outside that belt. They are primarily lakes of post-glacial origin related to melting of blocks of dead ice.

The Garwolin Plain is an area where no palynological investigations have been conducted previously. The study area is in the southern zone of the occurrence of sites with sediments of the Eemian interglacial, constituting only a part of this large lakeland (Żarski 2017, Żarski et al. 2017a, b). During cartographic work performed for updating of

Corresponding author the Garwolin sheet of the Detailed Geological Map of Poland (1:50000 Scale) (Żarski 2017), numerous sites were identified containing biogenic sediments age-correlated with the Eemian interglacial (Żarski 2017), as indicated by pollen analysis of random samples from several profiles, including the WH-15 Struga profile (Dąbrowska et al. 2017). South of the Garwolin Plain, in a belt of land adjacent to the Vistula River valley, only single sites with sediments of the Eemian interglacial have been documented, including sites in Kletnia Stara near Dęblin (Żarski 1989), Wola Okrzejska near Okrzeja (Żarski et al. 2005), and Kontrowers near Żelechów (Kupryjanowicz et al. 2003).

In 2016, a preliminary geological and geomorphological reconnaissance at WH-15 Struga revealed a thick series of organogenic sediments underlying fluvioglacial sediments. The palynology of 22 random samples of gyttja 
and peat supported the Eemian age of the studied series (Pidek 2016).

The Eemian lakeland in central Poland has been studied by Żarski et al. (2005), Bruj and Roman (2007), Roman (2016) and others in the last decades. Our detailed palynological investigation of the newly discovered Eemian sediments of the WH-15 Struga profile on the Garwolin Plain is offered as a contribution to our knowledge of changes in the palaeoenvironment of that area, including its palaeoclimate.

\section{STUDY AREA AND LITHOLOGY}

The WH-15 Struga site is about $1 \mathrm{~km}$ north of Puznówka village in the valley of the river of the same name (Struga), at ca $138.5 \mathrm{~m}$ a.s.l. (Fig. 1). The valley is a transformed post-glacial channel. In Puznówka village it changes direction from latitudinal to meridional. The valley is incised about a dozen metres. On both sides of the valley floor, river terraces from the period of the Weichselian glaciation are developed. Above them are kame terraces built of silty and fine-grained sands. The terraces are directly adjacent to a plateau built of boulder clay. The WH-15 core was taken in the valley floor and reached $20 \mathrm{~m}$. The limnic sediment series was drilled at depths in the $2.5-14 \mathrm{~m}$ range. The 14-7.4 m depth range contains fine-grained sands and glaciolacustrine muds of the Saalian glaciation deposited in a periodic through-flow waterbody. Boulder clays of the Saalian glaciation occur at $17.4-20 \mathrm{~m}$ depth.

The limnic series begins with non-calcareous grey gyttja $2.1 \mathrm{~m}$ thick, transitioning to calcareous olive green and dark green gyttja $1.5 \mathrm{~m}$ thick. The formations accumulated in a lake at the end of the Saalian glaciation. At ca $10.5 \mathrm{~m}$ depth a boundary is observed on the lithology core between the late glacial and Eemian interglacial. Calcareous gyttja continues from $10.5 \mathrm{~m}$ to $3.95 \mathrm{~m}$ depth. Admixtures of multi-grained sands occur at depths of $9.70-9.50 \mathrm{~m}$ and $5.30-4.80 \mathrm{~m}$. The sequence of Eemian limnic sediments ends with peat $1.45 \mathrm{~m}$ thick (3.95$2.50 \mathrm{~m}$ ). Formations of the Eemian interglacial are covered by fluvial sands with gravel of the Weichselian glaciation (2.50-0.3 m) underlying Holocene humic sands.

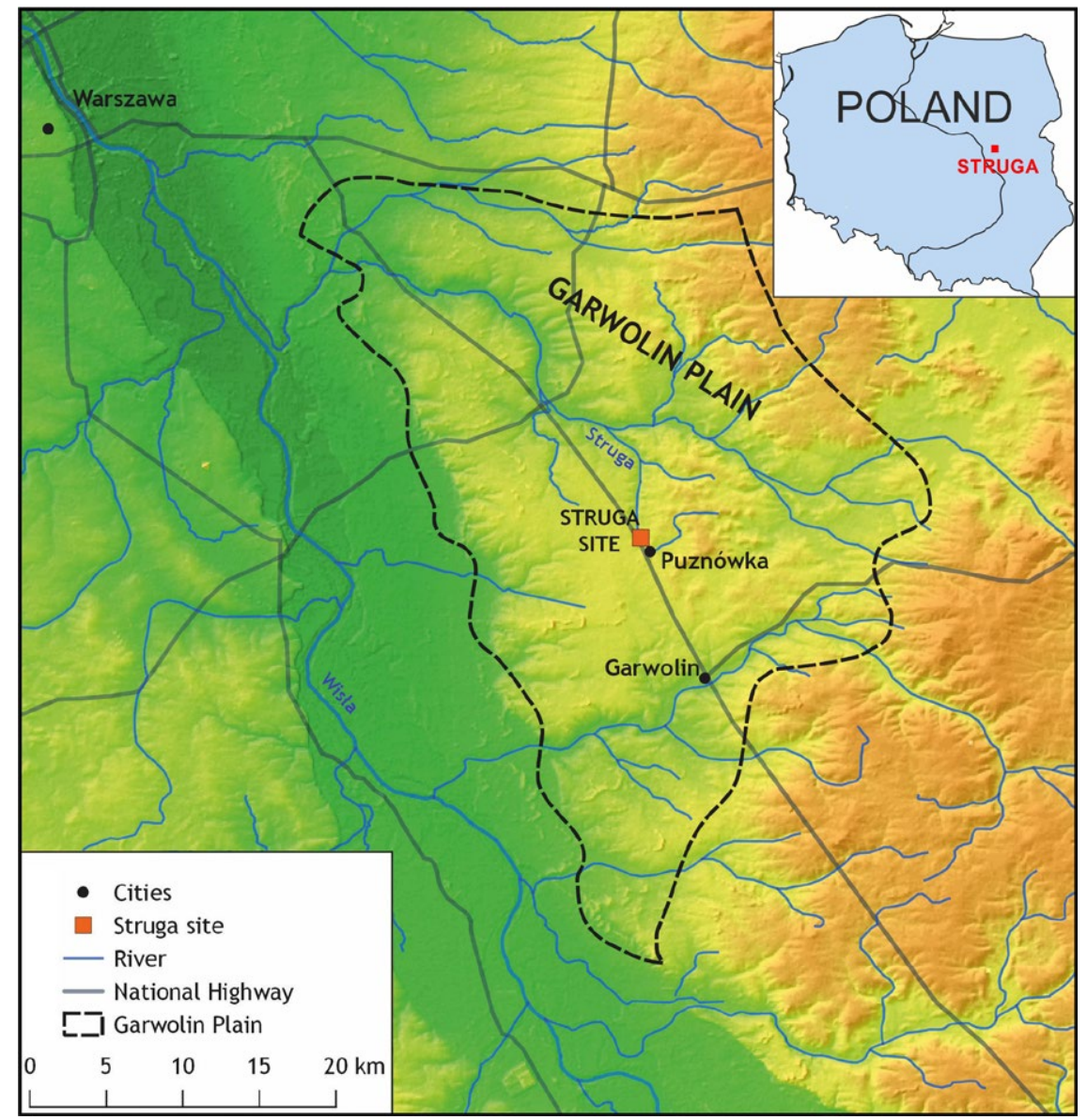

Fig. 1. Location of the study site (A. Bober) 


\section{STUDY MATERIAL AND METHODS}

Material for palynological research was collected from the WH-15 Struga core. The organogenic series is $8.8 \mathrm{~m}$ thick (11.5-2.7 $\mathrm{m}$ depth). We used 47 samples from the series for palynological analysis.

Laboratory processing of the samples for pollen analysis followed the standard procedure (Berglund \& Ralska-Jasiewiczowa 1986). After decalcification in $10 \% \mathrm{HCl}$ and boiling in $3.5 \% \mathrm{KOH}$, the mineral fraction was removed by flotation. The samples were then macerated by Erdtman acetolysis. Pollen spectra were calculated from at least two slides until 700-1000 pollen grains had been analysed. In the late glacial section the very low frequency of sporomorphs made it sometimes necessary to make counts from four slides to reach a minimum 300 pollen grains. The total amount of pollen of trees and shrubs (AP) and dwarf shrubs and herbaceous terrestrial plants (NAP) was taken as $100 \%$. The percentage shares of pollen of aquatic plants, spores, redeposited sporomorphs and colonies of algae of the genera Pediastrum and Botryococcus were calculated versus the adopted standard (total AP and NAP) but with the given taxon added before calculating its share.

The results of palynological analyses are presented in Table 1 and in a pollen diagram (Fig. 2) plotted using POLPAL software (Nalepka \& Walanus 2003) divided into Local Pollen Assemblage Zones (L PAZ), which were assigned to Regional Pollen Assemblage Zones (R PAZ according to Mamakowa 1989).

\section{STUDY RESULTS}

Table 1 and the pollen diagram of the WH-15 Struga profile (Fig. 2) show that the organogenic series covers local pollen assemblage zones from St-1 to St-8 L PAZ. Zone St-1 L PAZ is characterized by low frequency and poor preservation of sporomorphs. Herbaceous plants (NAP) and Pinus sylvestris t. reach their highest shares. NAP are dominated by Cyperaceae, Artemisia and Chenopodiaceae. The pollen spectra show dominance of steppe-tundra assemblages. The high Pinus sylvestris t. pollen values are probably related to long-range transport. Some of the birch pollen grains (Betula) showed features of Betula nana t. pollen, suggesting the occurrence of shrub tundra assemblages on the landscape. The open character of the landscape is also suggested by Juniperus and Ephedra as well as Hippophaë and Selaginella selaginoides. Such a pollen spectrum composition suggests that the lake began to develop in the glacial environment before the Eemian interglacial. The occurrence of Ceratophyllum hair-like leaves in the upper part of St-1 L PAZ testifies to the presence of Ceratophyllum species in the water.
Further samples from the St-2 L PAZ and St-3 L PAZ show expansion of Betula and Pinus sylvestris $t$. and the decline of NAP, reflecting the development of boreal forests, initially birch and then pine-birch. Together, the continuous presence of Ulmus pollen and appearance of Quercus pollen point to the beginning of the development of riverine forests as a result of progressive warming. Together with elm, the oak Quercus robur, a tree preferring wet habitats more than Quercus sessilis does, was probably part of the composition of the developing riparian forests. Granoszewski (2003) made such a suggestion in interpreting the pollen diagram of the Horoszki Duże site.

Very high shares of Quercus pollen (probably two species of oak) in the St-4 L PAZ suggest the expansion of oak in different habitats. With pine it could develop mixed pine-oak communities, with elm it could develop riparian forests, and with hazel, ash and lime it could form mixed deciduous communities. The high content of Quercus pollen is accompanied by indicators of warm and humid climate (e.g. Hedera helix and Buxus), the continuous curve of Humulus, and continuous curves of the shares of Fraxinus, Corylus and Alnus. Riparian and mixed deciduous communities may also have included Acer. Its pollen grains occur in this zone. Ceratophyllum sp. and Nuphar sp. were present in the lake at that time, while the surrounding reedswamp vegetation was composed of Typha latifolia and Phragmites australis. Equisetum spores and pollen of several herbs typical of wetter communities (Thalictrum, Mentha t.) confirm their presence close to the lake shores.

In the samples from the St-5 L PAZ the share of Corylus rises considerably and reaches its culmination $(81.5 \%)$. Its sharp increase is accompanied by a very rapid decrease of the Betula pollen curve. Those high values strongly suggest the dominance of hazel in different habitats. Granoszewski (2003) suggests that probably it was only an admixture in oak forests with lime, ash and maple, but also developed patches of warm hazel thickets following the type of modern Peucedano cervariae - Coryletum thickets (Matuszkiewicz 2000). Increasing values of Alnus pollen suggest the expansion of alder forest to humid areas, where it could form alder-ash riparian forests, and also alder carrs in poorer habitats and closed-drainage depressions. A decrease in the share of oak in the zone and an increase 
Table 1. Characteristics of the local pollen assemblage zones (LPAZs) in the WH-15 Struga profile near Puznówka

\begin{tabular}{|c|c|c|c|}
\hline $\begin{array}{l}\text { L PAZ } \\
\text { number }\end{array}$ & L PAZ name & $\begin{array}{l}\text { Sample } \\
\text { section }\end{array}$ & Description \\
\hline St-8 & Pinus & $270-410 \mathrm{~cm}$ & $\begin{array}{l}\text { Pinus and Betula values continue to increase, up to } 85.5 \% \text { and } 20.5 \% \text { respec- } \\
\text { tively. Alnus values fall to } 1 \% \text {. Picea decreases sharply and then continues at } \\
\text { ca } 1-2 \% \text {. Very significant decrease of curves of Ulmus, Quercus, Corylus, Carpi- } \\
\text { nus, Abies and Tilia. NAP increases again: Artemisia to } 2.5 \% \text {, Poaceae to } 3.5 \% \text {, } \\
\text { Cyperaceae to } 2.5 \% \text {. Continuous curve also characterizes Chenopodiaceae. }\end{array}$ \\
\hline St-7 & Picea-Abies-Alnus & $420-490 \mathrm{~cm}$ & $\begin{array}{l}\text { Increase of Pinus to } 30 \% \text { and Betula to } 6.5 \% \text { in upper part of zone. Continuous } \\
\text { and sharply increasing pollen curve for Abies, with maximum of } 18 \% \text {. Picea } \\
\text { culminates next (maximum of } 30 \% \text { ), with Alnus values still high: up to } 23 \% \text { in } \\
\text { lower part of zone and } 11 \% \text { in upper part. Carpinus, Corylus, Quercus, Ulmus } \\
\text { and Tilia values fall significantly. Pollen of thermophilous taxa absent. }\end{array}$ \\
\hline St-6 & $\begin{array}{l}\text { Carpinus-Corylus- } \\
\text { Alnus }\end{array}$ & $520-670 \mathrm{~cm}$ & $\begin{array}{l}\text { Predominance of Carpinus through the whole zone, with maximum of } 59 \% \\
\text { in upper part of zone. Tilia values still high (up to } 8.5 \% \text { ) in older part of } \\
\text { zone, falling to } 1.8 \% \text { in upper samples. Alnus 11-16.5\%. Taxus pollen fre- } \\
\text { quent. Large share of Quercus ( } 8 \% \text { ) in the beginning, decreasing in upper part; } \\
\text { similar trend for Corylus. Continuous curve of Picea shows low values. Pinus, } \\
\text { Betula and NAP show the lowest values of the profile. }\end{array}$ \\
\hline St-5 & $\begin{array}{l}\text { Corylus-Quercus- } \\
\text { Tilia }\end{array}$ & $700-770 \mathrm{~cm}$ & $\begin{array}{l}\text { Sharp increase and culmination of Corylus to } 81.5 \% \text {. Simultaneous decrease } \\
\text { in Quercus to } 4.9 \% \text {. Alnus values increase in upper part of zone to } 28 \% \text {, with } \\
\text { simultaneous increase of Tilia to } 10 \% \text { and Carpinus to } 7.5 \% \text {. Regular presence } \\
\text { of Taxus pollen grains. }\end{array}$ \\
\hline St-4 & $\begin{array}{l}\text { Quercus-Fraxinus- } \\
\text { Ulmus }\end{array}$ & $800-870 \mathrm{~cm}$ & $\begin{array}{l}\text { Sharp increase in Quercus pollen to maximum of } 59 \% \text { in uppermost sample } \\
\text { of zone. Simultaneous increase in Ulmus, reaching maximum of } 5 \% \text { in upper } \\
\text { part of zone. Significant fall of Pinus to } 18 \% \text { and Betula to } 4 \% \text {. Continuous } \\
\text { low curve of Corylus increases rapidly to } 9-14 \% \text { in upper part of zone. Low } \\
\text { percentages of Alnus pollen. Occurrence of Tilia pollen and sporadic pollen } \\
\text { grains of Carpinus, Hedera helix, Acer and Humulus. }\end{array}$ \\
\hline St-3 & $\begin{array}{l}\text { Pinus-Betula- } \\
\text { Ulmus }\end{array}$ & $880-940 \mathrm{~cm}$ & $\begin{array}{l}\text { Constant predominance of Pinus and Betula and increase of Ulmus to } 2.5 \% \\
\text { and Quercus to } 4.9 \% \text {. NAP values still declining. }\end{array}$ \\
\hline St-2 & Pinus-Betula & $970-1040 \mathrm{~cm}$ & $\begin{array}{l}\text { Increase of Pinus and Betula to } 58-59 \% \text {, with simultaneous decrease of NAP } \\
\text { in upper part of zone to Cyperaceae } 0.8 \% \text {, Artemisia } 1.0 \% \text {, Poaceae } 2.4 \% \text {. } \\
\text { Continuous curves of Ulmus, Quercus begins. Sporadic pollen of Picea. Pre- } \\
\text { Quaternary taxa absent. }\end{array}$ \\
\hline St-1 & $\begin{array}{l}\text { Cyperaceae- } \\
\text { Poaceae-Artemisia }\end{array}$ & $1080-1150 \mathrm{~cm}$ & $\begin{array}{l}\text { Low frequency and rather poor presevation of sporomorphs. High NAP values, } \\
\text { mainly Cyperaceae (up to 58.5\%), Artemisia (up to 3.5\%). Maximum of Salix } \\
\text { (3.5\%). Continuous curve of Juniperus. Presence of Hippophaë and Ephedra } \\
\text { fragilis t. as well as pre-Quaternary rebedded pollen. Probably also pollen } \\
\text { grains of thermophilous taxa such as Carpinus, Corylus and Quercus are } \\
\text { rebedded. Numerous pollen grains indeterminable due to destruction. }\end{array}$ \\
\hline
\end{tabular}

in the share of lime, as well as the beginning of the continuous curve of Carpinus, suggests the transformation of mixed deciduous assemblages dominated by lime and hornbeam. Pollen grains of Taxus, associated with warm climate with oceanic features, also occur. Its appearance, together with high shares of alder and the presence of Hedera helix, Ilex and Buxus, strongly suggests humidification of the climate. Taxus could enter more humid assemblages such as alder forest, especially since it is a shade-tolerant tree (Zarzycki et al. 2002) and can occur as a tree of the lower layer, for example under tree crowns of alder forest. At the same time, NAP reaches minimum values in this zone. This suggests that all the available habitats were occupied by forest communities of various types.

The St-6 L PAZ is dominated by Carpinus. Its culmination ( $>59 \%)$ is accompanied by a sharp decrease in Corylus and a considerable decrease in Tilia and Quercus. Such changes suggest the development of mixed deciduous forests dominated by hornbeam, with a slight admixture of other trees. This community may have resembled modern Tilio-Carpinetum. Acer also appeared in these forests, either Acer platanoides or Acer pseudoplatanus or both. Riparian assemblages were not subject to such radical metamorphoses as mixed deciduous ones were. Ash-elm riparian and alder-ash forests still developed, as well as alder carrs. Yew and maple may have been part of the tree composition of different kinds of more humid forests. The low share of Picea abies pollen suggests a slight admixture of spruce, probably in alder forests. In the upper part of the zone, single Abies pollen grains also suggest the beginning of the expansion of fir, probably in the same assemblages as spruce. Research on modern pollen 


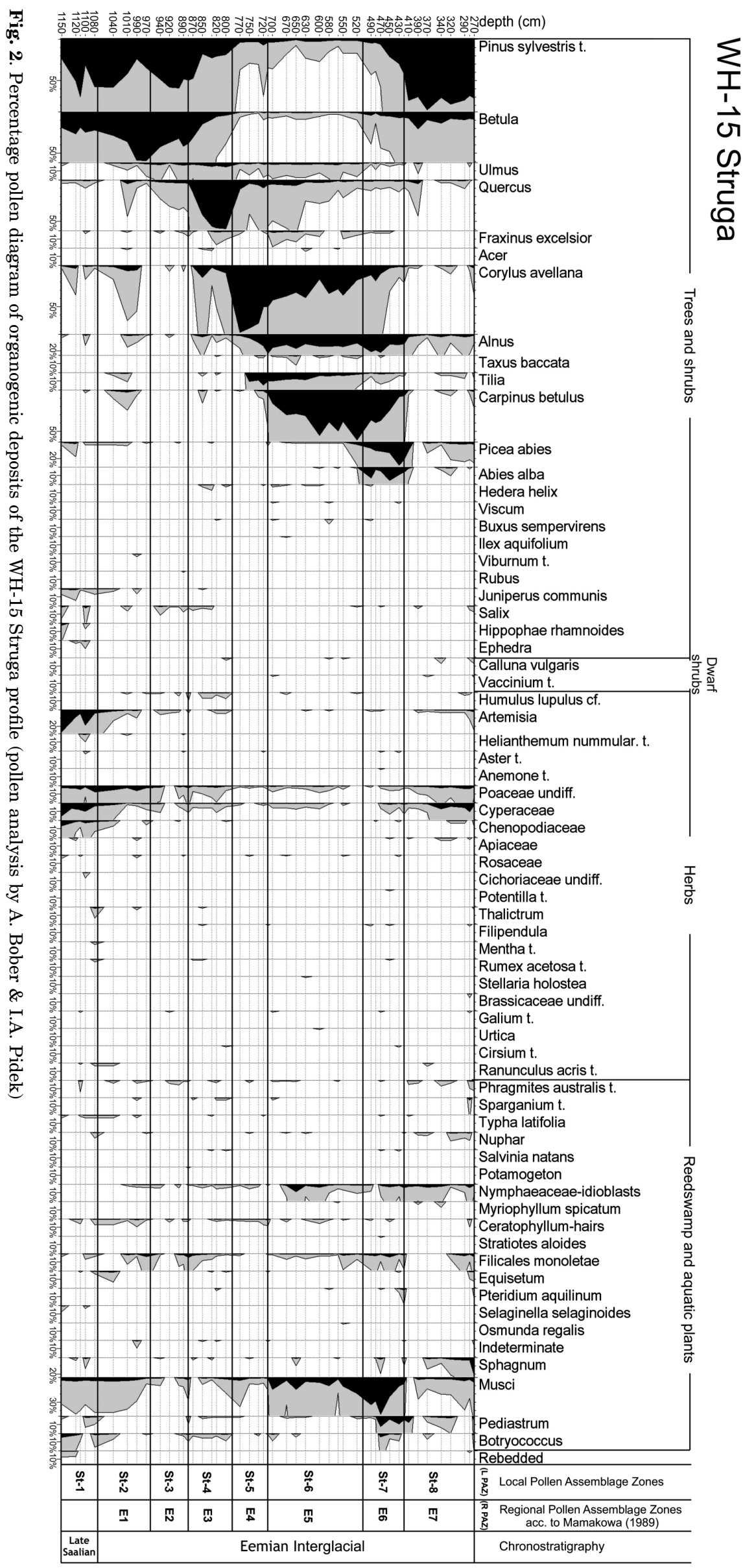


deposition indicates that heavy fir pollen is not spread long-distance in high amounts (Pidek et al. 2013). From this it can be inferred that in the dense tree stands of the climatic optimum of the interglacial, even sporadic Abies pollen grains suggest the presence of single fir trees in the tree communities (Pidek et al. 2013). Single pollen grains of plants indicating warm climate with gentle winters occur throughout the St-6 L PAZ: Viscum, Ilex, Hedera helix and Buxus. Sporadic pollen of Nuphar and reedswamp plants (Phragmites australis t., Sparganium t.) may mean that the lake was big and rather deep at that time.

In the St-7 L PAZ the shares of all thermophilic taxa: Carpinus betulus, Tilia, Quercus, Fraxinus excelsior, Ulmus, Corylus avellana, Acer, Hedera helix, Buxus sempervirens, and Ilex pollen all decline. The shares of Picea, Abies and Pinus sylvestris t. pollen increase significantly. The shares of Alnus are somewhat higher than in the St-6 L PAZ. Salix pollen grains begin to appear sporadically. In the upper part of the zone, pollen of herbaceous plants, particularly Cyperaceae and Poaceae, is more frequent. In humid habitats there were fir and spruce assemblages, probably natural succession stages overgrowing alder forests. In poorer sandy habitats, pine forests returned. Two sub-zones can be distinguished in the pollen zone: lower, with culmination of Abies; and upper, with culmination of Picea. Such changes probably occurred as a result of climate cooling. In the middle part the zone, Viscum pollen occurs together with the fir culmination. This semi-parasite of different deciduous trees does not develop when the coldest-month mean temperature falls below $-1.5^{\circ} \mathrm{C}$ (Iversen 1944). The upper sample of the zone shows a very significant decrease in fir and alder, a rapid increase in spruce and pine, a slight increase in birch, and the absence of indicators of warmer climate, suggesting a period of considerable cooling in which boreal trees (pine, spruce, birch) found conditions favouring their development. Spruce could then grow in habitats previously occupied by alder forests and fir assemblages. The increase in Musci spores may be partly related to the rich moss layer in these wet forests. The lake was probably more eutrophic, as evidenced by the presence of microsporangium tissue of Salvinia natans, a water fern overgrowing the surface of eutrophic waterbodies (Święta-Musznicka et al. 2011). The increasing values of Pediastrum colonies, among which Pediastrum simplex var. clathratum occurs, have same ecological significance. Komárek \& Jankovská (2001) relate this species with eutrophic reservoirs with neutral to alkaline water.

In the St-8 L PAZ, Pinus sylvestris t. pollen is largely predominant. The composition of the pollen spectrum reflects broad expansion of boreal pine forests with a slight admixture of birch, spruce and alder in humid habitats. Towards the top of the zone is seen a gradual increase of open areas overgrown with herbaceous plants. The sporadic pollen grains of thermophilic trees (Tilia, Quercus, Carpinus) probably were redeposited from older periods. The two uppermost samples with a still-high share of Pinus sylvestris t. are characterized by an increase in the amount of herbaceous plant pollen, suggesting further expansion of open areas on the landscape.

\section{DISCUSSION}

The presented vegetation succession is typical of the end phase of the Saalian (Warthe) glacial and Eemian interglacial. The zones of the interglacial seem complete; that is, they contain regional pollen zones from E1 to E7 (Mamakowa 1989). Our determination of the age of the analysed sediments is based on diagnostic features for the Eemian succession provided by Mamakowa (1989) and by Janczyk-Kopikowa (1974). Also used were correlations with the Eemian succession reconstructed based on high-resolution studies from eastern Poland (Granoszewski 2003, Kupryjanowicz 2008).

The St-1 L PAZ corresponds with the zone called LG MPG Cyperaceae-Artemisia-Betula nana R PAZ (Mamakowa 1989). Due to the relatively long distances between the palynological samples in the lower section of the WH-15 Struga profile, it is difficult to unambiguously determine the occurrence of a zone there that can be correlated with another late glacial zone (i.e. Hippophaë-Betula or NAP-HippophaëJuniperus), characterizing the late glacial section of the diagram from Warszawa-Wawrzyszew (Krupiński \& Morawski 1993). The last diagram represents another late glacial succession variant (Mamakowa 1989). It was considered typical of the central Poland pattern of vegetation development at the decline 
of the Saalian ice sheet (Granoszewski et al. 2012), and was compared by the mentioned authors to the late glacial part of the pollen succession of Dziewule (Bińka \& Nitychoruk 2001), in which Hippophaë taxa do not play a major role. The occurrence of the NAP-PiceaPinus zone, characteristic of profiles from eastern Poland, with a substantial share of spruce (Mamakowa 1989), is also rather improbable. Higher percentages of spruce pollen correspond somewhat with late glacial pollen zones with Picea obovata, typical for south-western Belarus and western Russia at the decline of the Pripiatskovo (=Saalian/Warthe) glaciation (Granoszewski et al. 2012). The thick series of sediments of the late glacial of the Saalian glaciation is representative not only for WH-15 Struga but also for the neighbouring Niesadna and Michałówka sites, analysed as part of the work on the Garwolin sheet of the Detailed Geological Map of Poland (1:50000 Scale) (Pidek 2016). Further studies of the late glacial series from the Garwolin Plain should produce palaeoenvironmental conclusions regarding the presence or absence of small-scale climate oscillations during this period. According to Turner (2000), however, no such oscillations of the scale of the Younger Dryas preceding the Holocene should be expected.

A broad overview of Eemian pollen successions across temperate areas west and north of the European Plain (Zagwijn 1996, Turner 2000) points to their remarkable consistency, probably the result of the opening of a seaway from the English Channel to the White Sea through the North Sea and Baltic Sea. These brought a mild, warm oceanic climate from the beginning of the interglacial and promoted rapid succession of the vegetation. Published data from the partially varved cores of Bispingen (Müller 1974), Quakenbrück (Hahne et al. 1994) and Gross Todtshorn (Caspers 1997) made it possible to determine the duration of the whole Eemian interglacial (10000 to 11000 years), and Caspers et al. (2002) were able to infer extreme sea level changes and their timing on the North Sea coast. They noted a much faster sea level rise at the beginning of the Eemian interglacial than at the beginning of the Holocene.

The whole Eemian interglacial pollen succession, divided in Poland into seven R PAZs according to Mamakowa (1989), correlates well with the Belarussian division of the same succession by Savchenko and Rylova (2001, cited in Granoszewski et al. 2012). In the latter division, R PAZs are labelled $\mathrm{mr}$ (=Muravian interglacial) and numbered from 1 to 9 . The number of regional pollen assemblage zones is higher in Belarus than in Poland, due to the distinction of mr4 (Corylus-Quercus-Tilia) and mr5 (TiliaCorylus-Carpinus) as separate zones, which have been treated as one zone (E4 R PAZ) in the Polish zonation. Similarly, zones $\mathrm{mr} 7$ and $\mathrm{mr} 8$ correspond to one zone (E6 R PAZ) in the Polish scheme (Tab. 2). The Polish zonation into

Table 2. Correlation of the L PAZs of the WH-15 Struga with R PAZs for Poland (acc. to Mamakowa 1989), Northern Germany (acc. to Turner 2002) and Belarus (acc. to Granoszeski et al. 2012)

\begin{tabular}{|c|c|c|c|c|}
\hline $\begin{array}{l}\text { Local Pollen Assemblage } \\
\text { Zones } \\
\text { WH-15 Struga }\end{array}$ & $\begin{array}{l}\text { Regional Pollen Assem- } \\
\text { blage Zones for Poland } \\
\text { acc. Mamakowa (1989) }\end{array}$ & $\begin{array}{l}\text { Regional Pollen Assemblage } \\
\text { Zones for Belarus } \\
\text { acc. Savchenko, Rylova } \\
\text { (2001) }\end{array}$ & $\begin{array}{c}\text { Regional Pollen } \\
\text { Assemblage Zone for } \\
\text { Northern Germany } \\
\text { acc. Turner (2002) }\end{array}$ & Stage \\
\hline $\begin{array}{l}\text { St-8 Pinus } \\
2.70-4.10 \mathrm{~m}\end{array}$ & E7 Pinus & mr9 Pinus & \multirow{2}{*}{ E6 Pinus-Picea-Abies } & \multirow{10}{*}{ 蛋 } \\
\hline St-7 Picea-Abies-Alnus & F6 Piced-Ahios-Alnus & mr8 Picea-Pinus & & \\
\hline $4.20-4.90 \mathrm{~m}$ & 上o Flcea-Aoles-Alnus & mr7 Carpinus-Picea & \multirow{2}{*}{ E5 Carpinus-Picea } & \\
\hline \multirow{2}{*}{$\begin{array}{l}\text { St-6 Carpinus-Corylus-Alnus } \\
5.20-6.70 \mathrm{~m}\end{array}$} & \multirow{2}{*}{$\begin{array}{l}\text { E5 Carpinus-Corylus- } \\
\text { Alnus }\end{array}$} & \multirow{2}{*}{ mr6 Carpinus-Tilia } & & \\
\hline & & & \multirow{3}{*}{$\begin{array}{l}\text { E4 Corylus-Taxus- } \\
\text { Tilia }\end{array}$} & \\
\hline \multirow{2}{*}{$\begin{array}{l}\text { St-5 Corylus-Quercus-Tilia } \\
7.00-7.70 \mathrm{~m}\end{array}$} & \multirow{2}{*}{ E4 Corylus-Quercus-Tilia } & mr5 Tilia-Corylus-Carpinus & & \\
\hline & & mr4 Corylus-Quercus-Tilia & & \\
\hline $\begin{array}{l}\text { St-4 Quercus-Fraxinus-Ulmus } \\
8.00-8.70 \mathrm{~m}\end{array}$ & $\begin{array}{l}\text { E3 Quercus-Fraxinus- } \\
\text { Ulmus }\end{array}$ & mr3 Quercus-Pinus-Corylus & \multirow{2}{*}{$\begin{array}{l}\text { E3 Pinus-Quercetum } \\
\text { mixtum }\end{array}$} & \\
\hline $\begin{array}{l}\text { St-3 Pinus-Betula-Ulmus } \\
8.80-9.40 \mathrm{~m}\end{array}$ & E2 Pinus-Betula-Ulmus & mr2 Pinus-Betula-Quercus & & \\
\hline $\begin{array}{l}\text { St-2 Pinus-Betula } \\
9.70-10.40 \mathrm{~m}\end{array}$ & E1 Pinus-Betula & mr1 Pinus-Betula-Picea & E2 Pinus-Betula & \\
\hline $\begin{array}{l}\text { St-1 Cyperaceae-Poaceae- } \\
\text { Artemisia } \\
10.80-11.50 \mathrm{~m}\end{array}$ & $\begin{array}{l}\text { Cyperaceae-Artemisia- } \\
\text { Betula nana }\end{array}$ & $\begin{array}{l}\text { pt-3-f- NAP-Pinus-Picea } \\
\text { obovata }\end{array}$ & $\begin{array}{l}\text { E1 Betula-Hippophae- } \\
\text { Juniperus-NAP }\end{array}$ & $\begin{array}{l}\text { LATE } \\
\text { SAALIAN }\end{array}$ \\
\hline
\end{tabular}


regional PAZs correlates well with the one proposed by Turner (2000) (Tab. 2).

The St-2 and St-3 L PAZs from WH-15 Struga, which represent the protocratic period of the Eemian interglacial, correspond with the regional E1-E2 R PAZ according to Mamakowa (1989) and mr1-mr2 of the Belarussian palynostratigraphic scheme (Granoszewski et al. 2012). The early expansion of elm and oak starting from the St-2 and St-3 L PAZs reflects the influence of oceanic climate.

The pollen spectra of the St-4-St-7 L PAZs particularly show features characteristic of optimum phases of the Eemian succession E3-E6 R PAZ. In the E3 R PAZ, correlated with the St-4 L PAZ, the occurrence of rich mixed deciduous forest is observed, reflected in the pollen diagram in high shares of pollen of Quercus (max. 59\%), Ulmus and Fraxinus, as well as the occurrence of Hedera. Granoszewski et al. (2012) point to a significant difference between the Polish and Belarussian pollen diagrams in that part of the succession: the absence of Abies and Taxus in the latter.

The St-5 L PAZ of Corylus-Quercus-Tilia is particularly interesting, correlated with the E4 R PAZ with very high culmination of hazel (81.5\%) and the almost simultaneous culmination of Tilia (10\%). The maximum values of lime should be assessed as very high because it is an entomophilous tree not producing high amounts of pollen. Values of ca $10 \%$ are considered high for the Polish Eemian sites in this zone, while at the Belarussian sites they reach as much as $55.8 \%$ (Granoszewski et al. 2012). Such a pattern of maximum values of the pollen curves of hazel and lime suggests the occurrence of the "early lime" variant within phase E4 in the palynological diagram from WH-15 Struga, similar to sites from the Warsaw vicinity: Warszawa-Błonie in Janczyk-Kopikowa (1974), and Warszawa-Żoliborz and WarszawaWola in Raniecka-Bobrowska (1954). As at WH-15 Struga, at many Eemian sites the presence of Taxus is recorded in this zone, suggesting the influence of humid oceanic climate (Kupryjanowicz et al. 2017), which situates the WH-15 Struga site in the transitional zone between oceanic and continental climate types further to the east. It should be stressed that Taxus is a very important component of Western European pollen diagrams, seen in the names of the pollen zones: for example, Corylus-Taxus-Tilia in northern Germany (Turner
2002) and Corylus-Quercus-Taxus at Grande Pile in France (de Beaulieu \& Reille 1992).

In the E5 R PAZ, correlated with the St-6 L PAZ, the abundant occurrence of pollen of Carpinus (more than 59\%) and still-high shares of Tilia confirm that hornbeam together with lime formed the primary component of the tree stands. Much higher Carpinus values appeared in pollen diagrams from eastern Poland (Granoszewski 2003). In Belarus they reach as high as $80 \%$ (Granoszewski et al. 2012). A comparison of the pollen shares of Taxus, Tilia and Carpinus, which were among the most important components of Eemian forests during the thermal optimum, leads to some conclusions: high synchronicity of vegetation development, and a sharp decrease of the humidity gradient towards the eastern part of the North European Plains, promoting the spread of lime and hornbeam towards the East, while the occurrence of Taxus and Abies communities was confined to more western areas.

The pollen diagram from WH-15 Struga has very significant values of Abies pollen, preceding the Picea ones in the zone St-7 LPAZ. In the pollen diagram from WH-15 Struga, the maximum for Abies precedes the Picea maximum in the St-7 LPAZ. For Polish Eemian sites it is typical for the silver fir maxima to occur first. According to Granoszewski (2003), the mesotrophic habitats of lime-hornbeam communities are suitable for the spread of fir. Although silver fir is a tree of mountain and upland areas nowadays, in North European lowlands its communities were widespread in the last part of the Eemian climatic optimum. They reach $10 \%$ at the Dziewule site (Bińka \& Nitychoruk 2001) and $2.5 \%$ at Horoszki-Duże. As with Taxus, Abies is totally absent from the Belarussian sites, while in northern Germany it is a component of the zone labelled Pinus-Picea-Abies. These details further support the suggestion of a strong W-E humidity gradient across Europe.

The hornbeam phase of the Eemian interglacial (E5 R PAZ) in many profiles from Poland contains hiatuses and different types of disturbance, linked by Kupryjanowicz (2008) with a substantial drop of the groundwater level, presumably caused by melting of the permafrost to a considerable depth during the optimum of the interglacial. Sites with hiatuses in the hornbeam phase are adjacent to sites without sedimentation breaks. Discussions of such issues based on Eemian profiles from 
northern Podlasie region (Kupryjanowicz 2008, Kupryjanowicz et al. 2017) have not resolved which factors caused those palaeohydrological disturbances. Moreover, the disturbances do not occur in all profiles, further complicating the problem. Our present work reveals a long palynological record of the hornbeam phase of WH-15 Struga, with an evident beginning, culmination and end of the phase, and a gradual retreat of hornbeam due to climate cooling, accompanied by the appearance of fir and spruce in the assemblages. The hornbeam phase in the WH-15 Struga profile extends through sediments more than $2.5 \mathrm{~m}$ thick. To solve the problem of potential disturbances, a sediment core sampled with a Geoprobe should be analysed, and the palynological data from several Eemian profiles from cores investigated in separate studies should be correlated.

Further palaeobotanical study of the WH-15 Struga profile together with data from other newly discovered Eemian sites on the Garwolin Plain (Niesadna, Michałówka), which have preliminary pollen-based age determinations, will help resolve palaeoecological, palaeoclimatic, and palaeoenvironmental issues regarding the period from the Late Saalian glaciation to the Early Weichselian in central Poland. No significant climatic cooling has been recorded in the St-8 LPAZ from WH-15 Struga so far, but an analysis of the uppermost section of the profile (above $2.70 \mathrm{~m}$ ) may alter the picture. Cooling in the E7 Pinus R PAZ is seen in the Horoszki Duże and Solniki pollen diagrams, and in the Belarussian ones (Granoszewski et al. 2012, Kupryjanowicz 2008). Pollen data from countries to the west of Poland suggest unstable conditions in the late Eemian. For example, annually laminated sediments from the Eifel region and northern Germany point to widespread dust dispersal in Central Europe, called the Late Eemian Aridity Pulse (Seelos \& Sirocko 2007).

\section{CONCLUSIONS}

The WH-15 Struga site is among several new sites of the Eemian interglacial on the Garwolin Plain, which is the southern part of an extensive Eemian lakeland.

Local pollen assemblage zones (L PAZs) from WH-15 Struga cover the whole Eemian interglacial and part of the Saalian late glacial preceding the interglacial succession. They have been correlated with regional pollen assemblage zones (R PAZ) for the Eemian interglacial E1-E7 analysed by Mamakowa (1989) and related to the division of the Eemian pollen successions from neighbouring countries (Belarus, Germany).

The thick series of the late glacial of the Saalian glaciation is representative of the WH-15 Struga site and also the neighbouring Niesadna and Michałówka sites analysed for the work on the Garwolin sheet for the Detailed Geological Map of Poland (1:50 000 Scale). In our study of the WH-15 Struga pollen succession we found no evidence of significant climate oscillations on the scale of the Younger Dryas preceding the Holocene.

All the Eemian interglacial R PAZs are represented in the WH-15 Struga pollen diagram, but significant differences in the pollen spectra, such as the early presence of Taxus and high Abies values, distinguish the WH-15 Struga pollen succession from the Belarussian ones. These features point to more humid climatic conditions in central Poland and situate the WH-15 Struga pollen sequence between western Eemian sites with Taxus and Abies and Eastern European ones without these components in the pollen spectra.

Since the Eemian organogenic sediments are thick and the palynological material is well preserved, a detailed analysis of the entire series of limnic sediments may help solve some palaeoecological and palaeoclimatic problems related to the end of the optimum of the Eemian interglacial, including hypotheses regarding rapid drying in the hornbeam phase (Kupryjanowicz 2008), labelled E5 R PAZ in the regional pollen stratigraphy for the Eemian interglacial (Mamakowa 1989).

Further palaeobotanical and palaeoclimatic studies should help identify another climate oscillation suggested at the decline of the E5 (Carpinus-Corylus-Alnus) R PAZ and/ or the decline of the interglacial in the E7 (Pinus) R PAZ.

\section{ACKNOWLEDGEMENTS}

We thank Dr Wojciech Granoszewski and the anonymous reviewer for their valuable comments and suggestions which helped to improve the manuscript.

This research received funding from the Faculty of Earth Sciences and Spatial Management, UMCS in Lublin (grant no. BS-P-12-011-17-D-01 and grant no. BS-M-12-011-17-3-05). 


\section{REFERENCES}

BEAULIEU J.-L. de \& REILLE M. 1992. The last climatic cycle at La Grande Pile (Vosages, France) a new pollen profile. Quat. Sci. Rev., 11: 431-438.

BERGLUND B.E. \& RALSKA-JASIEWICZOWA M. 1986. Pollen analysis: 455-484. In: Berglund B.E. (ed.), Handbook of Holocene Palaeoecology and Palaeohydrology. John Wiley \& Sons, Chichester New York - Brisbane - Toronto - Singapore.

BIŃKA K. \& NITYCHORUK J. 2001. Late Saalian climate changes in Europe in the light of pollen analysis and the problem of two-step deglaciation at the oxygen isotope stage $6 / 5$ e transition. Boreas, 30: $307-316$.

BRUJ M. \& ROMAN M. 2007. Zasięg pojezierza $\mathrm{z}$ interglacjału eemskiego $\mathrm{w}$ Polsce a pozycja stratygraficzna lądolodów zlodowaceń środkowopolskich. Biul. Państw. Inst. Geol., 425: 27-34.

CASPERS G. 1997. Die eem- und weichselzeitliche Hohlform von Groß Todtshorn (Kr. Harburg; Niedersachsen) - Geologische und palynologische Untersuchungen zu Vegetation und Klimaverlauf der letzten Kaltzeit. Schriftenreihe Deutsche Geologische Gesellschaf, 4: 7-59.

CASPERS G., MERKT J., MÜLLER H. \& FREUD H. 2002. The Eemian Interglaciation in Northwestern Germany. Quat. Res., 58: 49-52.

DĄBROWSKA A., PIDEK I.A. \& ŻARSKI M. 2017. Interglacjał eemski w profilu Struga (Równina Garwolińska): 10-11. In: Nalepka D. \& Stachowicz-Rybka R. (eds), VIII Polska Konferencja Paleobotaniki Czwartorzędu „Wpływ człowieka na roślinność Krakowa i okolic w okresie górnego czwartorzędu", Materiały konferencyjne, Instytut Botaniki im. W. Szafera PAN w Krakowie, Kraków.

GRANOSZEWSKI W. 2003. Late Pleistocene vegetation history and climatic changes at Horoszki Duże, E Poland: a palaeobotanical study. Acta Palaeobot. Suppl., 4: 1-95.

GRANOSZEWSKI W., WINTER H., RYLOVA T.B. \& SAVČENKO I.E. 2012. Przebieg i korelacja sukcesji pyłkowych późnego plejstocenu na terenie Polski i Białorusi. Przegl. Geol., 60(11): 605-614.

HAHNE J., KEMLE S., MERKT J. \& MEYER K.D. 1994. Eem-weichsel- und saalezeitliche Ablagerungen der Bohrung „Quakenbrück GE 2”. Geol. Jb. A, 134: 9-69.

IVERSEN J. 1944. Viscum, Hedera helix and Ilex as climatic indicators. A contribution to the study of the Post-Glacial temperature climate. Geologiska Föreningens i Stockholm Förhandlingar, 66: 463-483.

JANCZYK-KOPIKOWA Z. 1974. The Eemian Interglacial sediments at Błonie near Warsaw. Bulletin of Polish Academy of Scieces, Earth Sciences, 22: 147-150.

KOMÁREK J. \& JANKOVSKÁ V. 2001. Review of the Green Algal Genus Pediastrum; Implication for
Pollen-analytical Research. J. Cramer in der Gebrüder Borntraeger Verlagsbuchhandlung, Berlin.

KRUPIŃSKI M.K. \& MORAWSKI W. 1993. Geological position and pollen analysis of Eemian interglacial sediments of Warsaw-Wawrzyszew. Acta Palaeobot., 33(1): 309-346.

KUPRYJANOWICZ M. 2008. Vegetation and climate of the Eemian and Early Vistulian Lakeland in northern Podlasie. Acta Palaeobot., 48(1): 3-130.

KUPRYJANOWICZ M., ŻARSKI M. \& DRZYMULSKA D. 2003. Kontrowers - A new locality of the Eemian interglacial and the Early Vistulian at Żelechów Upland (eastern Poland). Acta Palaeobot., 43(1): 77-90.

KUPRYJANOWICZ M., NALEPKA D., PIDEK I.A., WALANUS A., BALWIERZ Z., BIŃKA K., FIŁOC M., GRANOSZEWSKI W., KOŁACZEK P., MAJECKA A., MALKIEWICZ M., NITA M., NORYŚKIEWICZ B. \& WINTER H. 2017. The eastwest migration of trees during the Eemian Interglacial registered on isopollen maps of Poland. Quat. Int., 467: 178-191. doi: https://doi.org/10.1016/j. quaint.2017.08.034.

MAMAKOWA K. 1989. Late Middle Polish Glaciation, Eemian and Early Vistulian vegetation at Imbramowice near Wrocław and the pollen stratigraphy of this part of the Pleistocene in Poland. Acta Palaeobot., 29(1): 11-176.

MATUSZKIEWICZ W. 2000. The systematic position of thermophilous beechwoods (CephalantheroFagenion) in Poland. Fragm. Flor. Geobot., 45(1-2): 393-412.

MÜLLER H. 1974. Pollenanalytische Untersuchungen und Jahresschichtenzählungen an der holsteinzeitlichen Kieselgur von Munster-Brehloh. Geol. Jahrb., A21: 107-140.

NALEPKA D. \& WALANUS A. 2003. Data processing in pollen analysis. Acta Palaeobot., 43: 125-134.

PIDEK I.A. 2016. Ekspertyza palinologiczna osadów organogenicznych z wiercenia wh-15, g-63 i g-267 ark. Garwolin, Szczegółowej mapy geologicznej Polski w skali 1: 50 000. Centralne Archiwum Geologiczne, Warszawa.

PIDEK I.A., SVITAVSKA-SVOBODOVA H., VAN DER KNAAP W.O. \& MAGYARI E. 2013. Pollen percentage thresholds of Abies alba based on 13-year annual records of pollen deposition in modified Tauber traps: perspectives of application to fossil situations. Rev. Palaeobot. Palynol., 195: 26-36.

RANIECKA-BOBROWSKA J. 1954. Analiza pyłkowa profilów czwartorzędowych Woli i Żoliborza w Warszawie. Biul. Inst. Geol., 69: 107-140.

ROMAN M. 2016. Pojezierze eemskie: uwagi o genezie i zaniku jezior polodowcowych centralnej Polski. Acta Geogr. Lodz., 105: 11-25.

SAVCHENKO I.E. \& RYLOVA T.B. 2001. Biostratigrafičeskoe rasčleneniemuravinskih i nižnepoozerskih otloženij plejstocena na territorii Belarusi. Doklady NAN Belarusi, 45(2): 93-98. 
SEELOS K. \& SIROCKO F. 2007. Abrupt cooling events at the very end of the Last Interglacial. Developments in Quaternary Science, 7: 207-222.

ŚWIETA-MUSZNICKA J., LATAŁOWA M., SZMEJA E.J. \& BADURA M. 2011. Salvinia natans in medieval wetland deposits in Gdańsk, northern Poland: evidence for the early medieval climate warming. J. Paleolimnol., 45(3): 369-383.

TURNER C. 2000. The Eemian Interglacial in the North European Plain and adjacent areas. Geologie en Mijnbouw/Netherlands Journal of Geosciences, 79: 217-231.

TURNER C. 2002. Formal Status ang Vegetational Development of the Eermian Interglacial in Northwestern and Southern Europe. Quat. Res., 58: 41-44.

ZAGWIJN W. 1996. An analysis of Eemian climate in western and cental Europe. Quat. Sc. Rev., 15: 451-469.

ZARZYCKI K., TRZCIŃSKA-TACIK H., RÓŻAŃSKI W., SZELĄG Z., WOŁEK J. \& KORZENIAK U. 2002. Ecological indicator values of vascular plant of Poland. Instytut Botaniki im. W. Szafera, Kraków.

ŻARSKI M. 1989. Nowe stanowisko interglacjału emskiego w okolicach Dęblina. Kwart. Geol., 33(2): 269-274.
ŻARSKI M. 2017. Szczegółowa Mapa geologiczna Polski w skali 1: 50000 ark. Garwolin. Manuskrypt. NAG Warszawa.

ŻARSKI M., NITA M. \& WINTER H. 2005. Nowe stanowiska interglacjalne w rejonie dolin Wilgi i Okrzejki na Wysoczyźnie Żelechowskiej (Polska południowo-wschodnia). Przegl. Geol., 53: 37-144.

ŻARSKI M., PIDEK I.A., HRYNOWIECKA A., KUPRYJANOWICZ M., FIŁOC M., SZAL M., STACHOWICZ-RYBKA R. 2017b. Nowe stanowiska interglacjału eemskiego na Równinie Garwolińskiej (E Polska) - doniesienie wstępne. In: D. Nalepka, R. Stachowicz-Rybka (eds). VIII Polska Konferencja Paleobotaniki Czwartorzędu „Wpływ człowieka na roślinność Krakowa i okolic w okresie górnego czwartorzędu”, Kraków, 6-9 czerwca 2017. Streszczenia referatów i posterów: 59-60.

ŻARSKI M., HRYNOWIECKA A., PIDEK A., KUPRYJANOWICZ M., FIŁOC M., SZAL M. \& STACHOWICZ-RYBKA R. 2017b. Geologiczne uwarunkowania pojezierza eemskiego na Równinie Garwolińskie. In: Materiały XXIV Konferencji Naukowo-Szkoleniowej Stratygrafia Plejstocenu Polski „Czwartorzęd pogranicza niżu i wyżyn w Polsce Środkowej” 4-8 września 2017 r. Wawrzykowizna k/Bełchatowa. Str 84 Uniwesytet Łódzki. ISBN 978-83-9344417-4-7 